\title{
The effect of L-arginine on slow motility of mammalian outer hair cell
}

\author{
Min-Jon Lin a, Mao-Chang $\mathrm{Su}^{\mathrm{a}}$, Ching-Ting Tan ${ }^{\mathrm{b}}$, Ching-Chyuan $\mathrm{Su}^{\mathrm{c}}$, Shuan-Yow Li a, \\ Ruey-Hseng Lin ${ }^{a}$, Shoei-Yn Lin-Shiau ${ }^{b}$, Chui-Chen Hung a, Shiann-Yann Lee ${ }^{b, *}$ \\ a Department of Life Sciences, Chung Shan Medical University, Taichung City, Taiwan \\ b Department of Otolaryngology, National Taiwan University Hospital, 7 Chung-Shan South Road, 100 Taipei, Taiwan \\ c Tong-Kong Teaching Hospital, Pingtung, Taiwan \\ Received 10 September 2002; accepted 7 January 2003
}

\begin{abstract}
The effect of L-arginine on the slow motility of mammalian cochlear outer hair cells was studied in this experiment. L-Arginine $(3 \mathrm{mM})$ but not D-arginine $(3 \mathrm{mM})$ or other amino acids (L-aspartate or L-glutamate) induced length increases of guinea pig outer hair cell. Similarly, the membrane-permeant cGMP analogues, 8-(4-chlorophenylthio)guanosine $3^{\prime}: 5^{\prime}$-cyclic monophosphate $(1 \mathrm{mM})$ or 8-bromo-guanosine $3^{\prime}: 5^{\prime}$-cyclic monophosphate $(1 \mathrm{mM})$ induced length increases of guinea pig outer hair cells. These length increases induced by L-arginine can be attenuated by a $30 \mathrm{~min}$ preincubation of the cells with the nitric oxide synthase inhibitors $N^{\mathrm{G}}$-nitro-L-arginine methyl ester hydrochloride $(3 \mathrm{mM})$ or 7 -nitroindazole $(1 \mathrm{mM})$. Comparing the effects of L-arginine and ionomycin on cell length and intracellular calcium change in outer hair cells, both L-arginine and ionomycin were able to induce the elongation of outer hair cells but L-arginine did not change the fluorescence intensity of Fluo-3. Preincubation of the cells with EGTA $(3 \mathrm{mM})$ for $40 \mathrm{~min}$ to reduce the extracellular calcium concentration did not influence the effect of $\mathrm{L}$-arginine. This experiment demonstrated that nitric oxide/cGMP pathway involvement in regulating the slow motility of mammalian outer hair cells cannot be ruled out. The effect of L-arginine is independent of extracellular calcium concentration.
\end{abstract}

(C) 2003 Elsevier Science B.V. All rights reserved.

Key words: Outer hair cell; Motility; L-Arginine; Nitric oxide; Calcium

\section{Introduction}

The outer hair cells play a very important role in sound transduction. Outer hair cells seem to act like tiny motors that amplify the movement of the basilar membrane during low-intensity sound stimuli. Recent studies demonstrated that prestin is required for electromotility of the outer hair cell (Liberman et al., 2002). The hair cells' motor is driven by the receptor potential, and it does not use ATP as an energy source (Kachar et al., 1986). It is also extremely fast, as it must be able to keep up with the movements induced by high-frequency

\footnotetext{
* Corresponding author. Fax: +886 (2) 2341-0905.

E-mail address: mjl@csmu.edu.tw (S.-Y. Lee).
}

Abbreviations: pCPT-cGMP, 8-(4-chlorophenylthio)guanosine $3^{\prime}: 5^{\prime}$-cyclic monophosphate; 8-Br-cGMP, 8-bromo-guanosine $3^{\prime}: 5^{\prime}$ cyclic monophosphate; L-NAME, $N^{\mathrm{G}}$-nitro-L-arginine methyl ester hydrochloride; 7-NINA, 7-nitroindazole; NOS, nitric oxide synthase sounds. The slow motility responses of outer hair cells can be elicited in response to osmotic pressure changes (Dulon et al., 1987), as well as to a variety to chemical stimuli (Zenner et al., 1985; Flock et al., 1986; Schacht and Zenner, 1987; Ulfendahl, 1987; Dulon et al., 1990). The increase of intracellular calcium level by ionomycin resulted in a length increase of mammalian outer hair cells through the activation of myosin light chain kinase and calcium/calmodulin-dependent protein kinase (Puschner and Schacht, 1997; Coling et al., 1998). Furthermore, external calcium was not required for the first outer hair cell contraction but essential for relaxation (Zenner et al., 1985). Because high potassium levels extracellularly can cause the shortening of outer hair cells but ionomycin induces the elongation of the cells, there is a need for further studies to clarify in detail the role of calcium both intra- and extracellularly. As we know, the NO/cGMP pathway actively regulating vascular smooth muscle involves decreasing the $\mathrm{Ca}^{2+}$ sensitivity 
(Blatter and Wier, 1994). Nitric oxide synthase (NOS) and guanylate cyclase are important regulatory enzymes in the cGMP pathway. NO-stimulated soluble guanylate cyclase activity was detected in supporting cells but not in outer hair cells (Fessenden and Schacht, 1997, 1998; Tian et al., 1999), but we cannot preclude the possibility in the synapse of outer hair cells. It has been reported the outer hair cell electromotility (fast motility) is modulated by the cGMP-dependent pathway (Szönyi et al., 1999). Furthermore, Shi et al. (2001) demonstrated the presence of NO in the outer hair cells of guinea pig using the NO fluorescent dye 4,5-diaaminofluorescein acetate. In these studies, we attempt to reveal whether L-arginine, a precursor of $\mathrm{NO}$, affects the slow motility of outer hair cells. The results showed that L-arginine but not $\mathrm{D}$-arginine increased the cell length of outer hair cells. The effect of L-arginine can be prevented by pretreatment with the NOS inhibitor $N^{\mathrm{G}}$-nitro-L-arginine methyl ester hydrochloride (L-NAME) or 7-nitroindazole (7-NINA). The elongation of outer hair cells induced by L-arginine is not only independent of extracellular $\mathrm{Ca}^{2+}$ concentration but the intracellular calcium concentration also had no increased effect. The effects of L-arginine were quite different from the effects of ionomycin on mammalian outer hair cells.

\section{Materials and methods}

Outer hair cells were isolated from guinea pigs (Hartley, National Laboratory Animal Breeding and Research Center, Taiwan) after enzymatic and mechanistic dissociation as described previously (Tan et al., 2001). Anesthetized guinea pigs (250-400 g) were decapitated and temporal bones quickly removed. The bulla and the bony walls of the cochlea were immediately opened and the organ of Corti dissected. Tissues and dissociated cells were handled in Hanks' balanced salt solution consisting of $137 \mathrm{mM} \mathrm{NaCl}, 5.4 \mathrm{mM} \mathrm{KCl}, 1.25 \mathrm{mM} \mathrm{CaCl}_{2}$, $0.5 \mathrm{mM} \mathrm{MgCl}, 0.4 \mathrm{mM} \mathrm{MgSO} 4,0.33 \mathrm{mM} \mathrm{Na}_{2} \mathrm{HPO}_{4}$, $10 \mathrm{mM}$ D-glucose and $5 \mathrm{mM}$ HEPES. The first two apical turns of the organ of Corti were collected and transferred into collagenase (type IV, Sigma) solution ( $1 \mathrm{mg} / \mathrm{ml}$ in Hanks' balanced salt solution). After 10 min digestion the pieces of the organ of Corti were placed in a coverslip chamber and the outer hair cells were isolated by gentle titration 3-5 times with a $20 \mu \mathrm{l}$ pipette under a stereomicroscope. Cell motility (contraction and elongation) was recorded for 5-10 $\mathrm{min}$ using a $40 \times$ or a $100 \times$ oil immersion objective on an inverted Zeiss microscope (Axiovert 25, Germany) fitted with a digital camera Axiocam (Zeiss, Germany). Analysis of length change was performed by the software AxioVision (Zeiss, Germany). Cell lengths were mea- sured as the distance between the cuticular plate and the synaptic ending of the cell. Cells were selected for measurement if they showed no obvious sign of damage, swelling, nucleus dislocation or granulation. The $\mathrm{pH}$ was adjusted to 7.35-7.40 with $\mathrm{NaOH}$ and the osmolarity to $310 \pm 3 \mathrm{mOsm}$. Osmolarity of the medium was checked before and after each experiment at room temperature $\left(24-27^{\circ} \mathrm{C}\right)$. Isolated apical outer hair cells ranging in length from 60 to $80 \mu \mathrm{m}$ were used for this experiment.

Changes of intracellular $\mathrm{Ca}^{2+}$ concentration in outer hair cells were determined using the fluorescent $\mathrm{Ca}^{2+}$ indicator Fluo-3/AM and a confocal laser scanning fluorescence microscope (Zeiss Confocal LSM410 equipped with an argon-krypton laser). Fluo-3/AM (Molecular Probes, Eugene, OR, USA) was dissolved in dimethyl sulfoxide (DMSO) and $3 \mu \mathrm{M}$ loaded into outer hair cells on coverslips for $40 \mathrm{~min}$. Cells loaded with Fluo-3 were observed with an inverted microscope (Zeiss Axiovert 135M, Germany), with excitation at 488 $\mathrm{nm}$ and emission at $525 \mathrm{~nm}$. The changes of intracellular calcium levels of outer hair cells were indicated by the relative Fluo-3 fluorescence intensity.

\subsection{Chemicals}

L-Arginine, D-arginine, L-NAME, 8-(4-chlorophenylthio)guanosine $3^{\prime}: 5^{\prime}$-cyclic monophosphate (pCPTcGMP), and 8-bromo-guanosine $3^{\prime}: 5^{\prime}$-cyclic monophosphate (8-Br-cGMP) were obtained from Sigma (St. Louis, MO, USA). 7-Nitroindazole (7-NINA) was obtained from Tocris (Ballwin, MO, USA). All drugs were dissolved in Hanks' balanced salt solution except Fluo-3 AM and pCPT-cGMP, which were dissolved in DMSO. The final total DMSO concentration did not exceed $1 \%$ in the bath medium. The osmolarity of all media for these experiments was kept at $310 \pm 3 \mathrm{mOsm}$.

\subsection{Statistics}

The values given are means \pm S.E.M. The significance of differences was evaluated by Student's $t$-test. When more than one group was compared with one control, significance was evaluated according to one-way analysis of variance (ANOVA). Probability values of $<0.05$ were considered to be significant.

\section{Results}

\subsection{L-Arginine but not D-arginine induced cell elongation}

A typical isolated outer hair cell with a bundle of cilia $(c)$ at the top and auditory nerve terminal (synapse, $s$ ) 

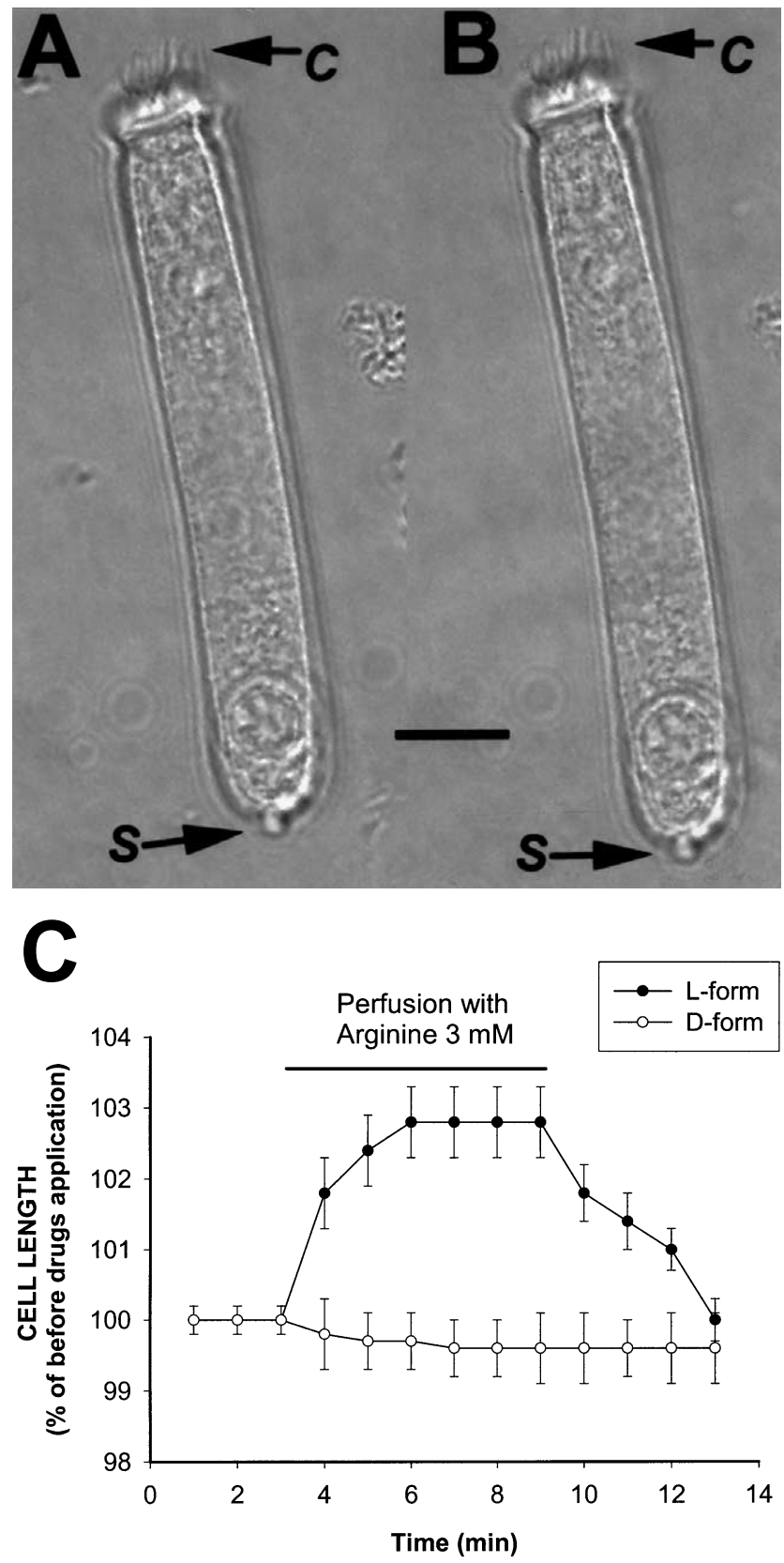

Fig. 1. Effect of the L- or D-form of arginine on the cell length change of isolated outer hair cells of guinea pig. (A) The picture shows a typical intact isolated outer hair cell with clearly visible bundle of cilia $(c)$ at the top and synapse $(s)$ at the bottom of the cell. The elongation of the cell can be induced by the application of $\mathrm{L}$-arginine $3 \mathrm{mM}$ (B, picture shows $130 \mathrm{~s}$ after the application of L-arginine). (C) The time course of the cell length change after perfusion with $3 \mathrm{mM}$ L- or D-arginine ( $n=4-6$ for each curve) on the outer hair cells. The cell length increment is shown as a percentage of the length before the addition of arginine. Scale bar in A and B: $12 \mu \mathrm{m}$. Values are mean \pm S.E.M. ${ }^{*} P<0.05$ as compared with before the addition of $\mathrm{L}-$ or $\mathrm{D}$-arginine. attached at the bottom of the cell is shown in Fig. 1A, and the picture $120 \mathrm{~s}$ after the addition of L-arginine $(3 \mathrm{mM})$ is shown in Fig. 1B. Application of L-arginine (3 $\mathrm{mM})$ was unable to induce a morphological change of the outer hair cell except for the cell elongation. Perfusion with L-arginine $(3 \mathrm{mM})$ but not D-arginine (3 $\mathrm{mM}$ ) induced the elongation of outer hair cells (Fig. 1C). The effect of L-arginine was reversible after washout. L-Arginine $(3 \mathrm{mM})$ but not L-glutamate $(3 \mathrm{mM})$ and L-aspartate $(3 \mathrm{mM})$ induced the elongation of outer hair cells. The effect of cell elongation reached a maximum about $100 \mathrm{~s}(102.8 \pm 0.6 \%, n=11$; Fig. 1C)

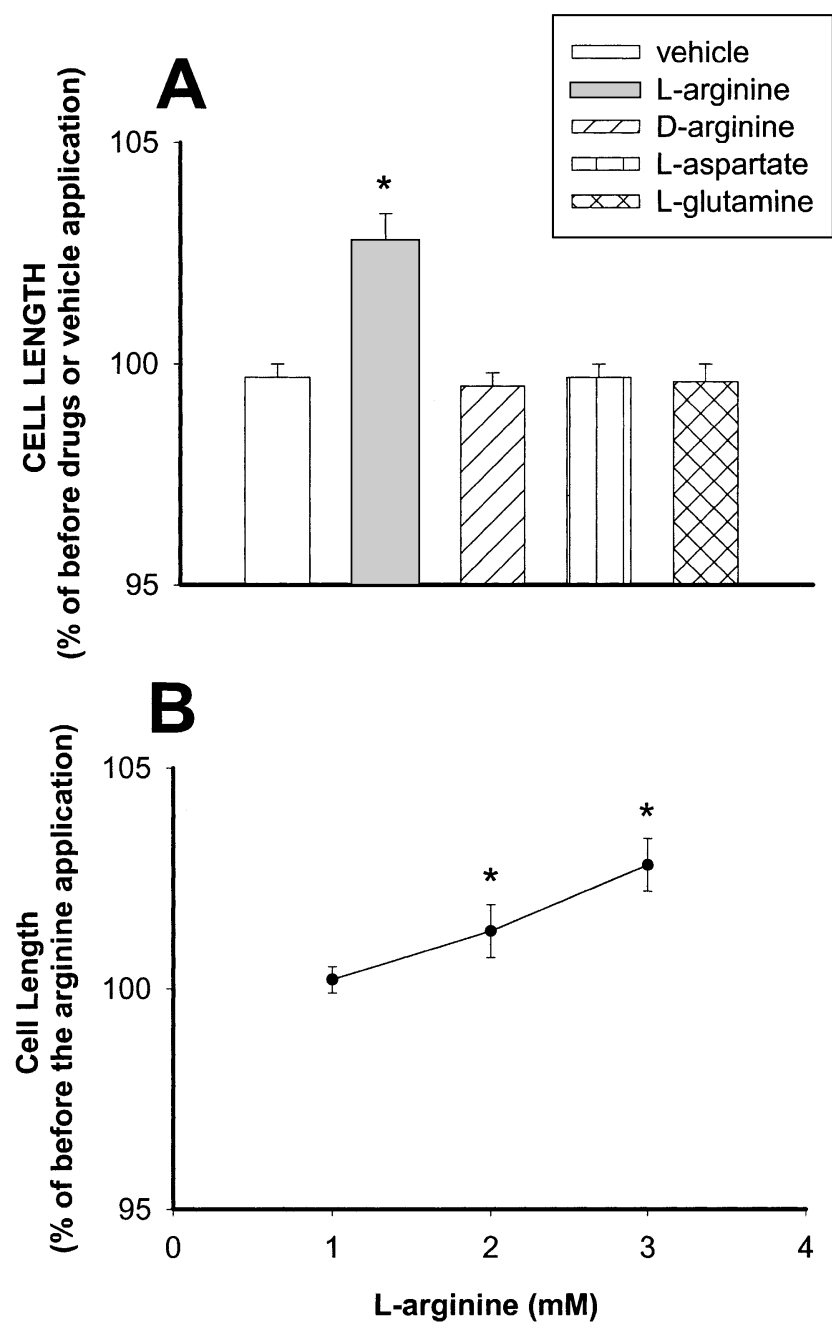

Fig. 2. Comparison of the effects of L-arginine, D-arginine, L-glutamate and L-aspartate on cell length change of outer hair cells. (A) The percentage of maximum length change of outer hair cells produced by four amino acids individually, L-arginine, D-arginine, L-glutamate or L-aspartate. L-Arginine ( $3 \mathrm{mM} ; n=11)$, but not other amino acids, D-arginine ( $3 \mathrm{mM} ; n=4)$, L-glutamate ( $3 \mathrm{mM} ; n=6)$, L-aspartate $(3 \mathrm{mM} ; n=5)$, or vehicle $(n=4)$, was able to induce the elongation of outer hair cells. Length change is shown as percent change from cell length at time zero (before the addition of $3 \mathrm{mM}$ amino acids). (B) Dose-response curve of L-arginine (1-3 mM). Values are mean \pm S.E.M. ${ }^{*} P<0.05$ as compared with vehicle (in A) or before the application of arginine (in B). 
after L-arginine was applied. Other amino acids, D-arginine ( $3 \mathrm{mM} ; 99.5 \pm 0.3 \% ; n=4)$, L-glutamate $(3 \mathrm{mM}$; $99.6 \pm 0.4 \% ; n=6)$ or L-aspartate $(3 \mathrm{mM} ; 99.7 \pm 0.4 \%$; $n=4)$, or vehicle $(99.7 \pm 0.3 \% ; n=4)$ were not able to change the cell length significantly (Fig. 2A). The doseresponse curve showed that $2-3 \mathrm{mM}$ of $\mathrm{L}$-arginine produce a significant increase of the length of cells (Fig. 2B). The highest concentration level of L-arginine $(10 \mathrm{mM})$ was able to induce a maximal length increase (114\% of before addition of L-arginine), accompanied by a significant morphological change (e.g., cell swelling, nucleus dislocation). Therefore a reasonable concentration of L-arginine ( $3 \mathrm{mM})$, which did not produce cell toxicity, was used throughout the experiment.

\subsection{NOS inhibitors attenuate the effect of L-arginine}

Preincubation of cells with the NOS inhibitors L-NAME (3 mM) (Fig. 3A,B) and 7-NINA (1 mM; Fig. 3B) for $30 \mathrm{~min}$ was able to reduce significantly

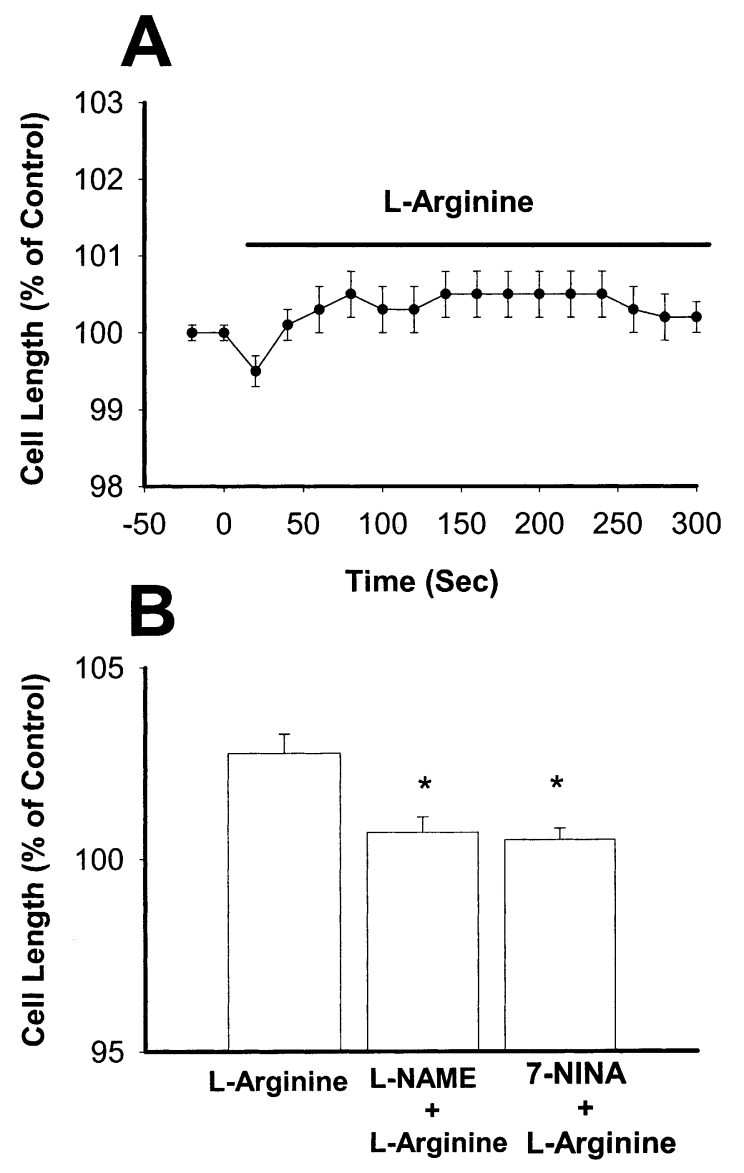

Fig. 3. Pretreatment with the NOS inhibitors L-NAME and 7-NINA caused a decrease in the effect of cell elongation induced by L-arginine. The cells were preincubated with the NOS inhibitor L-NAME $(3 \mathrm{mM})(A)$ or 7-NINA $(1 \mathrm{mM})$ (B) for $30 \mathrm{~min}$, L-arginine $(3 \mathrm{mM})$ did not cause a significant effect on the extension of outer hair cells. Values are mean \pm S.E.M. ${ }^{*} P<0.05$ as compared with control.

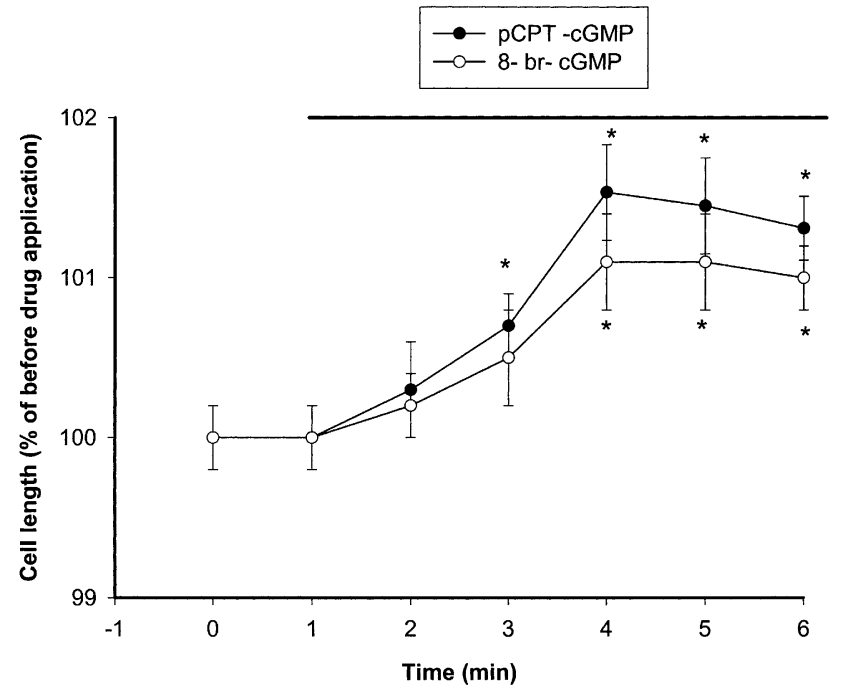

Fig. 4. Effect of the cGMP membrane-permeable analogues pCPTcGMP and 8-Br-GMP on the cell length change of outer hair cells. Application of pCPT-cGMP $(1 \mathrm{mM})$ or 8 -Br-GMP $(1 \mathrm{mM})$ was able to induce significant cell elongation of outer hair cells. Values are mean \pm S.E.M. ${ }^{*} P<0.05$ as compared with before the addition of pCPT-cGMP or 8-Br-GMP.

the cell elongation induced by L-arginine $(3 \mathrm{mM})$. The maximal length increases produced by pretreatment with L-NAME $(n=7)$ were $100.5 \pm 0.3 \%(P<0.05$ as compared with L-arginine alone; $102.8 \pm 0.6, n=11)$, and by pretreatment with 7-NINA $(n=5)$ were $100.7 \pm$ $0.4 \%(P<0.05$ as compared with L-arginine alone) (Fig. 3B).

\subsection{Membrane-permeant cGMP analogues induced cell elongation}

The cell-permeable cGMP analogues pCPT-cGMP $(1 \mathrm{mM})$ and 8-Br-cGMP $(1 \mathrm{mM})$ induced a cell elongation which reached a maximum at 4 min (Fig. 4). The maximal length induced by pCPT-cGMP was $101.5 \pm$ $0.3 \%$ of control $(P<0.05$ as compared with before drug application, $n=7$ ) and that induced by 8 -Br-cGMP was $101.10 \pm 0.30 \%(P<0.05$ as compared with before drug application, $n=5$ ). The vehicle alone experiment produced no significant effect on the length change of outer hair cells (maximal length change was $99.4 \pm 0.5 \%$ of before treatment, $n=4)$. The effects on outer hair cell elongation induced by cGMP analogues were significant but less potent than that of L-arginine.

\subsection{L-Arginine does not change the intracellular calcium level}

Addition of $3 \mathrm{mM}$ L-arginine had no effect on the change of Fluo-3 fluorescence intensity (Fig. 5A). However, the Fluo-3 fluorescence intensity was increased by the addition of high potassium medium $(75 \mathrm{mM} \mathrm{KCl}$ 

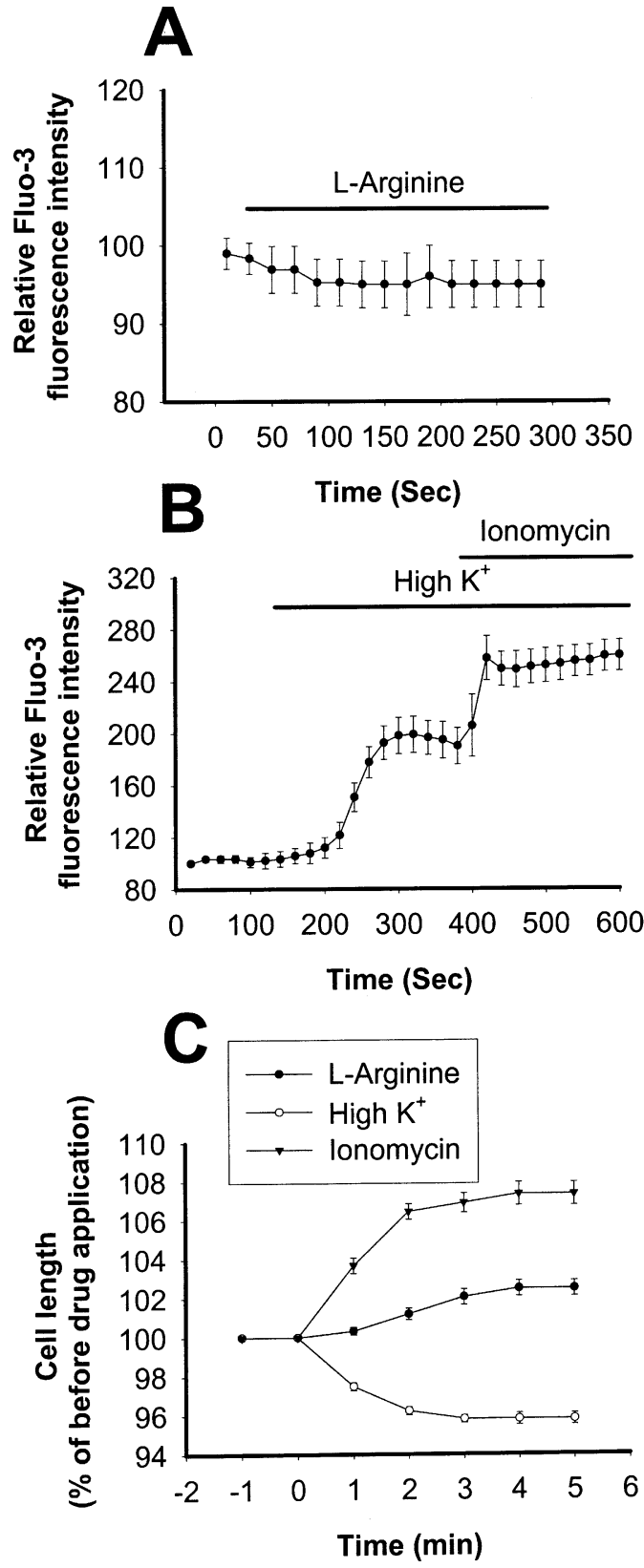

Fig. 5. Effect of L-arginine, high potassium or ionomycin on changes of intracellular Fluo-3 fluorescence intensity $(\mathrm{A}, \mathrm{B})$ and length (C) of outer hair cells. (A) L-Arginine $(3 \mathrm{mM})$ did not cause a significant change in the intracellular calcium level of outer hair cells. (B) Extracellular perfusion with high $\mathrm{K}^{+}(75 \mathrm{mM})$ medium alone or the subsequent application of ionomycin $(10 \mu \mathrm{M})$ produced a significant increase of the concentration of intracellular calcium. (C) A comparison of the effects of L-arginine, high potassium and ionomycin on the cell length change of outer hair cells. L-Arginine or ionomycin increased but high potassium decreased the cell length of outer hair cells. Note that there is no relation between the intracellular calcium level and the change of cell length. Values are mean \pm S.E.M. ${ }^{*} P<0.05$ when compared to before treatment. replacing equal molar $\mathrm{NaCl}$ ) and can be further enhanced by the subsequent addition of ionomycin (10 $\mu \mathrm{M})$ (Fig. 5B). The levels of intracellular calcium did not correlate with the cell length changes. Fig. 5C shows the time course of cell length changes, L-arginine or ionomycin inducing elongation but high $\mathrm{K}^{+}$inducing shortening of outer hair cells.

\subsection{The effect of L-arginine is independent of extracellular calcium concentration}

When the outer hair cells were incubated in calciumfree Hanks' balanced solution (supplemented with $3 \mathrm{mM}$ EGTA) for $40 \mathrm{~min}$, the addition of $3 \mathrm{mM}$ L-arginine still produced an elongating effect on outer hair cells
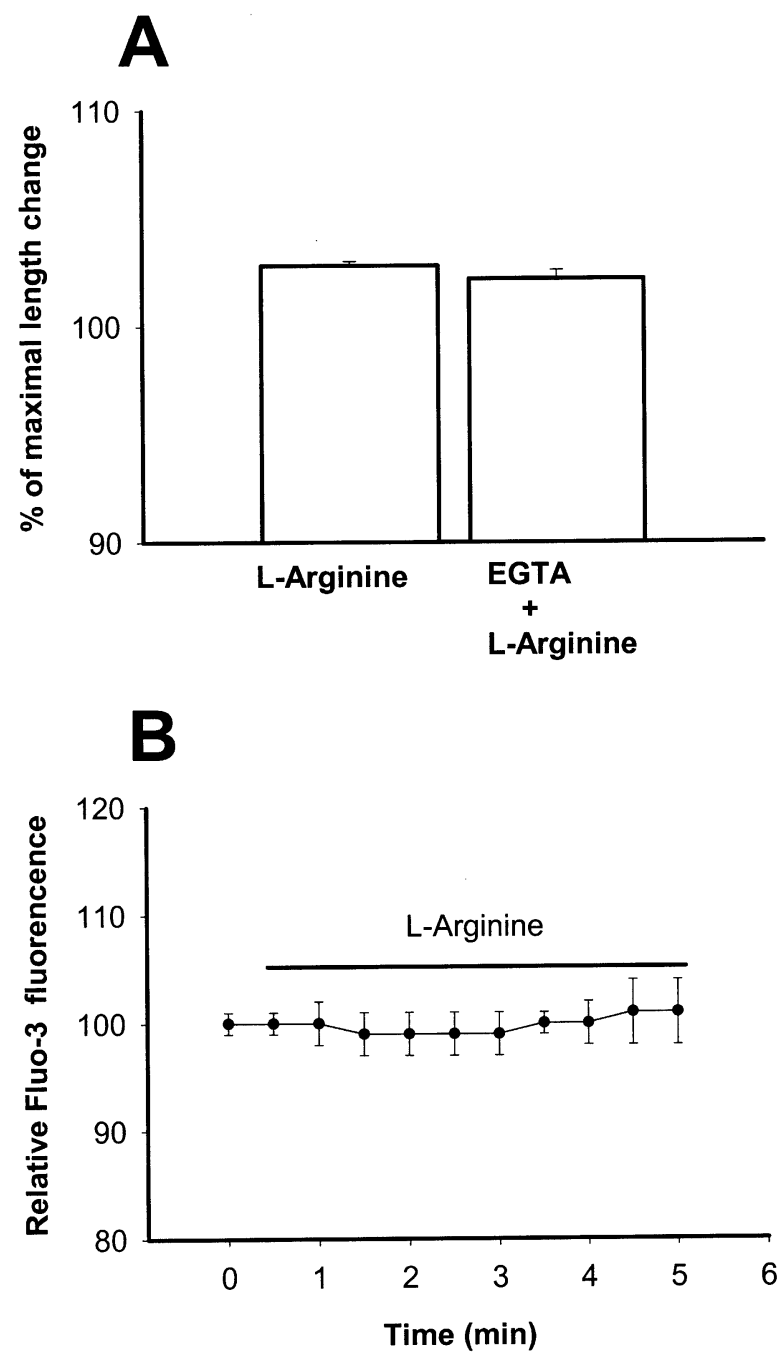

Fig. 6. Reducing the extracellular calcium concentration with EGTA $(3 \mathrm{mM})$ for $40 \mathrm{~min}$ did not alter the effect of $\mathrm{L}$-arginine on the percentage maximal elongation of outer hair cells (A). In the Fluo-3 calcium imaging study, L-arginine still did not produce a change in the intracellular calcium level when pretreated with EGTA (3 mM) for $40 \mathrm{~min}(\mathrm{~B})$. Values are mean \pm S.E.M. 
(Fig. 6A) but the level of intracellular calcium concentration remained unchanged (Fig. 6B).

\section{Discussion}

The present study showed that L-arginine but not D-arginine or other amino acids (L-aspartate or L-glutamate) induced the effect of extension of outer hair cells. Because the effect of L-arginine can be attenuated by pretreatment with NOS inhibitors (L-NAME or 7-NINA), NO/cGMP pathway involvement in the regulation of slow motility of outer hair cells cannot be ruled out. Furthermore, these results revealed that a $\mathrm{Ca}^{2+}$-independent pathway in the regulation of cell slow motility was quite different from the effect of ionomycin (Coling et al., 1998).

\subsection{The specific effect of L-arginine}

It has been reported that electrostatic interactions among the fibers comprising the pillars could lead to changes in cell length (Steele, 1990). Furthermore, electrostatic interaction between stereocilia may influence the mechanical properties of the hair bundle (Dolgobrodov et al., 2000). We tested the effect of four polar amino acids (L-arginine, D-arginine, L-aspartate and L-glutamate) individually on isolated outer hair cells in this study. The results showed that all polar amino acids except L-arginine were unable to induce elongation of outer hair cells. The effect of L-arginine was independent of its polar property. Because the D-form arginine had no effect on the elongation of outer hair cells, the effect of L-arginine is to be considered specific.

\subsection{Comparison between the effects of L-arginine and ionomycin}

The movement of outer hair cells can be induced by potassium (Zenner, 1986), electric stimulation as well as by ATP (Schacht and Zenner, 1987; Flock et al., 1986) and ionomycin (Dulon et al., 1990). The elevation of intracellular calcium by ionomycin in turn generates circumferential or cortical forces leading to a reduction of cell diameter and an elongation of the cell. The length increases induced by ionomycin can be inhibited by preincubation of the cells with myosin light chain kinase inhibitors or an inhibitor of $\mathrm{Ca}^{2+} /$ calmodulindependent protein kinase II (Puschner and Schacht, 1997; Coling et al., 1998). These data suggested that protein kinase activity regulates calcium-dependent processes that effect shape changes of outer hair cells. High potassium medium, similar to ionomycin, has been shown to increase intracellular calcium concentration but to cause a length shortening (contraction) of outer hair cells (Fig. 5B,C). Although the high potassium medium and ionomycin produce an increase of intracellular calcium level, their actions must be via a different mechanism. L-Arginine did not change the concentration of intracellular calcium but still produced an elongating effect on outer hair cells in the present study. It has been demonstrated that external calcium was required for relaxation of the contracted outer hair cells (Zenner et al., 1985; Dulon et al., 1990); the fact that the effect of L-arginine was independent of extracellular calcium provides another possible pathway to induce length increases of outer hair cells.

\subsection{NO/cGMP signaling pathway}

The NO/cGMP signaling pathway is important in several physiological functions including vascular smooth muscle relaxation, neuronal signal transduction and inhibition of platelet aggregation (Robbins and Grisham, 1997). It has been suggested that overstimulation of soluble guanylate cyclase may mediate NOinduced cochlear toxicity (Dais et al., 1996). Recent studies have proved the localization of NOS to nerve fibers in the organ of Corti (Michel et al., 1999). The target enzymes of NO, guanylate cyclase and protein kinase $G$, are seen in the supporting cells but not in the sensory hair cells. The NO/cGMP pathway could play a role in controlling calcium homeostasis of supporting cells and regulating cochlear blood flow (Fessenden and Schacht, 1998 Fessenden et al., 1999). In contrast, NO signal was observed in outer hair cells, afferent nerves and their putative endings near inner hair cells and efferent nerve endings near outer hair cells using the fluorescent dye 4,5-diaminofluorescein diacetate as indicator (Shi et al., 2001). The role of NO in the regulation of the motility of outer hair cells needs further investigation. Since the effects of L-arginine on the slow motility of outer hair cells can be attenuated by pretreatment with NOS inhibitors, we cannot rule out a possible role of the NO/cGMP pathway in the regulation of the slow motility of outer hair cells. Furthermore, it has been reported that outer hair cell electromotility is modulated by a cGMP-dependent pathway (Szönyi et al., 1999). Several possible mechanisms might produce the slow motility of outer hair cells induced by L-arginine. First, NOS and guanylate cyclase exist in auditory nerve terminals and $\mathrm{NO}$ as retrograde message may act on the postsynaptic membrane of outer hair cells. Second, the total amount of NOS and guanylate cyclase may be too low to be detectable. Third, L-arginine may act as a regulator of the membrane motor proteins of outer hair cells directly. The precise molecular mechanism remains to be established. Taken together, the present study demonstrates a calcium-independent cell elongation induced by L-arginine in outer 
hair cells. The effects of L-arginine revealed that a possible calcium- independent pathway could be involved in the regulation of outer hair cell motility.

\section{Acknowledgements}

This study was supported by research grants from the National Science Council, Taiwan (NSC 91-2314-B040-020) and Chung Shan Medical University (CSMU 90-OM-B-037).

\section{References}

Blatter, L.A., Wier, W.G., 1994. Nitric oxide decreases $\left[\mathrm{Ca}^{2+}\right]_{i}$ in vascular smooth muscle by inhibition of the calcium current. Cell Calcium 15, 122-131.

Coling, D.E., Bartolami, S., Rhee, D., Neelands, T., 1998. Inhibition of calcium-dependent motility of cochlear outer hair cells by the protein kinase inhibitor, ML-9. Hear. Res. 115, 175-183.

Dais, C.G., Prazma, J., Ball, S.S., Zdanski, C., Carrasco, V., Pillsbury, H.C., III, 1996. Effect of sodium nitroprusside on compound action potential thresholds in the gerbil cochlea. Hear. Res. 99, 16.

Dolgobrodov, S.G., Lukashkin, A.N., Russell, I.J., 2000. Electrostatic interaction between stereocilia: II. Influence on the mechanical properties of the hair bundle. Hear. Res. 150, 94-103.

Dulon, D., Aran, J.-M., Schacht, J., 1987. Osmotically induced motility of outer hair cells: implications for Meniere's disease. Arch. Otorhinolaryngol. 224, 104-107.

Dulon, D., Zajic, G., Schacht, J., 1990. Increasing intracellular free calcium induces circumferential contraction in isolated cochlear outer hair cells. J. Neurosci. 10, 1388-1397.

Fessenden, J.D., Schacht, J., 1997. Distribution of soluble guanylate cyclase activity suggests regulation of blood flow and supporting cell physiology in the inner ear. J. Histochem. Cytochem. 45, 1401-1408.

Fessenden, J.D., Schacht, J., 1998. The nitric oxide/cyclic GMP pathway: A potential major regulator of cochlear physiology. Hear. Res. 118, 68-176.
Fessenden, J.D., Altschuler, R.A., Seasholtz, A.F., Schacht, J., 1999. Nitric oxide/cyclic guanosine monophosphate pathway in the peripheral and central auditory system of the rat. J. Comp. Neurol. 404, 52-63.

Flock, A., Flock, B., Ulfendahl, M., 1986. Mechanisms of movement in OHCs and a possible structural basis. Arch. Otorhinolaryngol. 243, 83-90.

Kachar, B., Brownell, W.E., Altschuler, R., Fex, J., 1986. Electrokinetic shape changes of cochlear outer hair cells. Nature 322, 365-368.

Liberman, M.C., Gao, J., He, D.Z.Z., Wu, X., Jia, S., Zuo, J., 2002. Prestin is required for electromotility of the outer hair cell and for the cochlear amplifier. Nature 419, 300-304.

Michel, O., Hess, A., Bloch, W., Stennert, E., Su, J., Addicks, K., 1999. Localization of the NO/cGMP-pathway in the cochlea of guinea pigs. Hear. Res. 133, 1-9.

Puschner, B., Schacht, J., 1997. Calmodulin-dependent protein kinases mediate calcium-induced slow motility of mammalian outer hair cells. Hear. Res. 110, 251-258.

Robbins, R.A., Grisham, M.B., 1997. Molecules in focus: nitric oxide. Int. J. Biochem. Cell Biol. 29, 857-860.

Schacht, J., Zenner, H.P., 1987. Evidence that phosphoinositides mediate motility in cochlear outer hair cells. Hear. Res. 31, 155159.

Shi, X., Ren, T., Nutall, A.L., 2001. Nitric oxide distribution and production in the guinea pig cochlea. Hear. Res. 153, 23-31.

Steele, C., 1990. Elastic behavior of the outer hair cell wall. In: Dallos, P., Geisler, C.D., Matthews, J.W., Ruggero, M.A., Steele, C.R. (Eds.), The Mechanics and Biophysics of Hearing. Springer-Verlag, New York, pp. 76-83.

Szönyi, M., He, D.Z.Z., Ribari, O., Sziklai, I., Dallos, P., 1999. Cyclic GMP and outer hair cell electromotility. Hear. Res. 137, $29-42$.

Tan, C.T., Hsu, C.J., Lee, S.Y., Liu, S.H., Lin-Shiau, S.Y., 2001. Potentiation of noise-induced hearing loss by amikacin in guinea pigs. Hear. Res. 161, 72-80.

Tian, F., Fessenden, J.D., Schacht, J., 1999. Cyclic GMP-dependent protein kinase-I in the guinea pig cochlea. Hear. Res. 131, 63-70.

Ulfendahl, M., 1987. Motility in auditory sensory cells. Acta Physiol. Scand. 130, 521-527.

Zenner, H.P., 1986. Motile responses in outer hair cells. Hear. Res. 22, 83-90.

Zenner, H.P., Zimmermann, U., Schmitt, U., 1985. Reversible contraction of isolated mammalian cochlear hair cells. Hear. Res. 18, 127-133. 